TI 2014-109/VII

Tinbergen Institute Discussion Paper

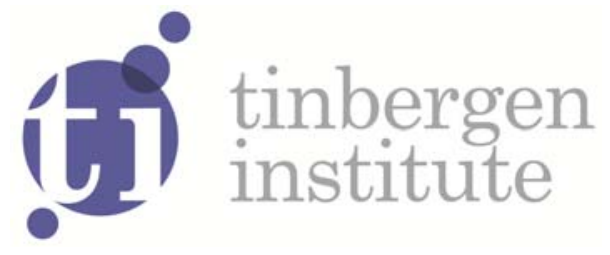

\title{
The Stature of the Self-employed and its Premium
}

Cornelius A. Rietveld

Jolanda Hessels*

Peter van der Zwan*

* Tinbergen Institute

Erasmus School of Economics, Erasmus University Rotterdam, the Netherlands. 
Tinbergen Institute is the graduate school and research institute in economics of Erasmus University Rotterdam, the University of Amsterdam and VU University Amsterdam.

More TI discussion papers can be downloaded at http://www.tinbergen.nl

Tinbergen Institute has two locations:

Tinbergen Institute Amsterdam

Gustav Mahlerplein 117

1082 MS Amsterdam

The Netherlands

Tel.: +31(0)205251600

Tinbergen Institute Rotterdam

Burg. Oudlaan 50

3062 PA Rotterdam

The Netherlands

Tel.: +31(0)10 4088900

Fax: $+31(0) 104089031$

Duisenberg school of finance is a collaboration of the Dutch financial sector and universities, with the ambition to support innovative research and offer top quality academic education in core areas of finance.

DSF research papers can be downloaded at: http://www.dsf.nl/

Duisenberg school of finance

Gustav Mahlerplein 117

1082 MS Amsterdam

The Netherlands

Tel.: +31(0)20 5258579 


\title{
The stature of the self-employed and its premium
}

\author{
Cornelius A. Rietveld ${ }^{a}$, Jolanda Hessels ${ }^{a, b, c}$, Peter van der Zwan ${ }^{a, b, c}$ \\ ${ }^{\text {a }}$ Erasmus School of Economics, Erasmus University Rotterdam, \\ P.O. Box 1738, 3000 DR, Rotterdam, the Netherlands \\ ${ }^{\mathrm{b}}$ Erasmus Happiness Economics Research Organisation (EHERO), Erasmus University Rotterdam \\ ${ }^{c}$ Tinbergen Institute
}

\begin{abstract}
Taller individuals typically have occupations with higher social status and higher earnings than shorter individuals. Further, entrepreneurship is associated with high social status in numerous countries; hence, entrepreneurs might be taller than wage workers. Using data from the German Socio-Economic Panel (2002-2010), we find that a $1 \mathrm{~cm}$ increase in an individual's height raises the probability of being self-employed (the most common proxy for entrepreneurship) versus paid employed by 0.16 percentage-points. Within self-employment the probability of being an employer is increased by 0.11 percentage-points as a result of a $1 \mathrm{~cm}$ increase in height whereas this increase is 0.05 percentage-points for an own-account worker. Furthermore, we confirm that a height premium in earnings exists for not only paid employees, as indicated by prior studies, but also for self-employed individuals. An additional $1 \mathrm{~cm}$ in height is associated with a $0.44 \%$ increase in hourly earnings for paid employees, and a $0.87 \%$ increase for self-employed individuals. The predicted earnings differences between short and tall individuals are substantial. Short paid employees - first quartile of height - earn 15.5 Euros per hour whereas tall paid employees - third quartile of height - earn 16.5 Euros per hour; in self-employment the earnings are 12.8 and 14.4 Euros per hour, respectively. Another novel finding is that we establish the existence of a height premium for work and life satisfaction, but only for paid employees. Finally, our analysis reveals that $44 \%$ of the height premium in earnings is explained by differences in educational attainment whereas the height premium in work and life satisfaction is only marginally explained by education.
\end{abstract}

Corresponding author: C.A. Rietveld, Erasmus School of Economics, Erasmus University Rotterdam, P.O. Box 1738, 3000 DR, Rotterdam, the Netherlands, nrietveld@ese.eur.nl, tel.: +31104088935, fax: +31104089141 .

Keywords: Self-employment, Stature, Height premium, Education, Life satisfaction

JEL codes: J24, J31

Acknowledgement: The authors would like to thank Roy Thurik for his valuable suggestions. The data used in this publication were made available to us by the German Socio-Economic Panel Study (SOEP) at the German Institute for Economic Research (DIW), Berlin.

Version: August 2014 


\section{Introduction}

Taller individuals typically have occupations with higher social status (Case and Paxson, 2006). For example, tall men are more likely to have a managerial position than short men (Lindqvist, 2012). While height itself is unlikely to cause these occupational differences, many researchers have sought to devise explanations wherein height is a correlate of a deeper cause. Most older studies in the literature emphasize social discrimination on the basis of height as the deeper cause. The newer studies argue that cognitive skills, non-cognitive skills, and height are interrelated and jointly determined to the extent that selection on these (non-)cognitive skills-rather than on height itselflargely explains the positive correlation between height and job status (Schick and Steckel, 2010).

Although cross-country variation exists in the status of a given occupation, entrepreneurship is associated with high social status in many countries. This association is driven at least to some extent by well-known examples of highly successful entrepreneurs such as Steve Jobs and Mark Zuckerberg. The Global Entrepreneurship Monitor, an annual international assessment of entrepreneurship, reveals that in many countries, most of the adult population (about 70 percent in developed countries in 2010) believes that individuals who are successful at starting a new business receive a high level of status and respect in their country (Kelley et al., 2011). Another international study on entrepreneurial activity - the most recent Flash Eurobarometer surveys conducted in 2009 and 2012 - indicates that among the working age population, opinions of entrepreneurs or self-employed individuals are much more favorable than opinions of corporate managers, civil servants, or politicians. ${ }^{1}$

The present paper is the first attempt to provide a detailed perspective on the relationship between height and occupational choice — self-employment versus paid employment — in a high-income country (Germany). Self-employment is an often-used proxy for entrepreneurship in empirical work (Parker, 2009) and is considered an important labor market status, composing approximately $10 \%$ of the labor force in Western countries (Van Stel, 2005). This paper has four aims, which are listed below.

First, the present paper investigates whether taller persons are more likely to be self-employed than paid employees. We expect to find a positive relationship between height and self-employment (versus paid employment) because of the relatively high level of status associated with entrepreneurship in Germany. Height has seldom been included in studies explaining occupational choice, and when it is included, it is usually not a primary variable of interest. For example, a working paper by Djankov et al. (2006) includes height as a control variable in a study on the determinants of entrepreneurship versus paid employment in Brazil, China, and Russia. The findings indicate that height is positively related to entry into entrepreneurship in Brazil but not in the other two countries.

\footnotetext{
${ }^{1}$ See: http://ec.europa.eu/public_opinion/flash/fl_283_en.pdf and http://ec.europa.eu/public_opinion/flash/fl_354_en.pdf
} 
We are unaware of any studies that investigate the relationship between height and occupational choice in a high-income country. In addition, within the group of self-employed individuals, we distinguish between employers and own-account workers. Employers are reported to have a higher level of (entrepreneurial) ability than own-account workers (De Wit, 1993; Congregado, Millán and Román, 2010). The ability to employ others is often considered a sign of business success, and employers earn more on average than own-account workers (Earle and Sakova, 2000; Tamvada, 2010). Because of the presumed higher status attached to employers relative to own-account workers, we expect height to better differentiate employers from wage workers than own-account workers from wage workers.

Second, our paper investigates whether a height premium in earnings exists within self-employment. Gowin (1915) already showed that there is considerable variation in height within occupational groups (in his case executives) that appears to be positively associated with job level. We also know that the height premium in earnings exists irrespective of occupational classes within paid employment (Case and Paxson, 2006, Persico, Postlewaite and Silverman, 2004, Schick and Steckel, 2010). The height premium for self-employed individuals has been investigated in one article using an Indonesian sample (Sohn, 2014). We extend this initial study by using a much larger dataset from a high-income country, Germany. The present research design enables a comparison of the height premium between self-employed individuals and paid employees.

Third, our study aims to infer whether a height premium exists in work and life satisfaction. As individuals also derive utility in life from aspects other than earnings, satisfaction is considered a more comprehensive measure of utility (Van Praag and Ferrer-i-Carbonell, 2010). Thus, work and life satisfaction are more encompassing proxies than financial returns for utility from work (Clark and Oswald, 1996; Frey and Stutzer, 2002; Benz and Frey, 2008). Furthermore, when occupational status is higher, non-monetary aspects of work may become more important (Fershtman and Weiss, 1993). Indeed, self-employment is typically associated with higher non-monetary returns than paid employment in higher income countries, e.g., in terms of work satisfaction (Blanchflower and Oswald, 1998; Blanchflower, 2000; Hundley, 2001; Benz and Frey, 2004, 2008; Bianchi, 2012; Millán et al., 2013). Empirical evidence also indicates that self-employed individuals are more satisfied with their lives than employees (Blanchflower and Oswald, 1998; Alesina et al., 2004; Andersson, 2008; Binder and Coad 2013). In summary, while prior studies typically focus on the height premium in earnings (Tao, 2014), a height premium might also exist for other outcomes. Nevertheless, this height premium in work and life satisfaction has not been the topic of prior studies. A study by Deaton and Arora (2009), however, focusing on the US population suggests that taller persons have more positive opinions of their lives (work satisfaction is not taken into account), which is primarily explained by their higher income and higher education level. The present study extends 
the analysis in Deaton and Arora (2009) by assessing whether a height premium in work and life satisfaction exists for self-employed individuals and paid employees.

Fourth, our study investigates the role of educational attainment in the height premium in earnings and satisfaction, for both self-employed individuals and paid employees. ${ }^{2}$ Sohn (2014) tentatively explains the height premium in earnings within self-employment by customer preferences for tall men and women. While customer preferences could explain why taller individuals remain in selfemployment, we believe that the differences in height within the group of self-employed individuals are too small to play a role in customer preferences. We therefore argue that educational attainment and more non-cognitive skills rather than customer preferences are largely responsible for the observed height premium. The present paper determines the extent to which educational attainment accounts for the height premium in earnings and satisfaction.

Using data from the German Socio-Economic Panel (GSOEP) for the period from 2002 to 2010, we provide a number of novel findings that complement the literature on height, occupational choice, and the height premium. Regarding the relationship between height and occupational choice, we find that an individual's height increases the likelihood that the individual is self-employed (the most common proxy for entrepreneurship) and in particular an employer rather than a paid employee. With respect to the existence of a height premium, we confirm that such a premium in earnings exists for the selfemployed and that this earnings premium is significantly higher for self-employed individuals than for paid employees. We also establish the existence of a height premium for work and life satisfaction, but only for paid employees and not for self-employed individuals. Finally, our findings indicate that educational attainment partially explains the height premium in earnings for both self-employed individuals and paid employees but has little role in explaining the height premium in work and life satisfaction. The latter finding suggests that non-cognitive skills in particular account for the presence of a work and life satisfaction premium.

\section{Data, methodology, and descriptive analysis}

We employ the GSOEP $^{3}$ to associate height with occupational choice, hourly earnings, work satisfaction, and life satisfaction. The GSOEP is a representative, longitudinal study of private households, administered by the German Institute for Economic Research, DIW Berlin. We choose

\footnotetext{
${ }^{2}$ Although we would have preferred to analyze the contribution of non-cognitive skills to the height premium, a convincing measure for non-cognitive skills remains elusive. Recently, Ter Weel (2008, p. 729) argued, "No single factor has emerged in the psychological literature and it is unlikely that one will be found, given the diversity of traits subsumed under the category of non-cognitive skills. More importantly, it is unclear how to include non-cognitive skills in the standard economic model." Therefore, in this study, we focus on educational attainment alone.

${ }^{3}$ http://www.diw.de/english/soep
} 
the GSOEP because entrepreneurs are accorded high social status in Germany. For example, nearly 80 percent of Germans believe that successful entrepreneurs have a high level of status and respect in their country (Kelley et al., 2011). The GSOEP data are gathered annually and are available from 1984 onward. The sample has been augmented and updated regularly. Our analyses are based on workers aged 18-65 years who participated in the study at least once during the 2002-2010 period (nine waves of the GSOEP) and who have height information for at least one year. An individual may have been interviewed multiple times during this period, and all collected information on occupational status, hourly earnings, work and life satisfaction, and the control variables is used for our analyses.

Self-reported height was obtained in the years 2002, 2004, 2006, 2008, and 2010. ${ }^{4}$ We take the average self-reported height across these five years of data collection (or fewer years if a respondent did not participate each year) to reduce the impact of self-reporting errors. As such, we generate one height measure for each individual who participated at least once during these five years. Furthermore, certain individuals appear to misjudge their height on some occasions. To account for such reporting anomalies - which may also be caused by the interviewer during data entry-we disregard individuals for whom the difference between the minimum and maximum self-reported height exceeds 5 centimeters. Height is very stable during adulthood and only declines slightly in old age, which justifies our approach of taking averages and excluding individuals with large selfreported height differences.

In the GSOEP, individuals are asked for their current occupational status. When employed in more than one position, the interviewee is asked to reveal his/her primary position. Although a broad distinction between occupational positions exists within the GSOEP, we distinguish between selfemployed individuals (where farmers are included) and individuals in paid employment (blue collar, white collar, civil service). Our dependent variable self-employed takes a value of 1 for selfemployment and 0 for paid employment. The number of employees for each self-employed individual is known, such that we can distinguish between employers and own-account workers in our analyses.

Total annual earnings in Euros are known for all workers. These earnings include not only the wages or income corresponding to an individual's occupational position(s) but also possible bonus compensation from work. In addition to annual earnings, total annual work hours are known. We generate the variable hourly earnings by dividing annual earnings by annual hours worked. Values of zero are not taken into account. The logarithm is then taken, which is common practice in research on income.

Respondents assess their satisfaction with their work and life as a whole on a scale from 0 (completely dissatisfied) to 10 (completely satisfied). Specifically, the following questions are asked: "All things

\footnotetext{
${ }^{4}$ Self-reported height was also collected in 2012, but we do not have access to the data for this year. Information on selfreported height from the GSOEP is also used in Hübler (2009).
} 
considered, how satisfied are you with your work?" for work satisfaction and "All things considered, how satisfied are you with your life?" for life satisfaction.

We perform binary logit regressions explaining self-employed to examine the relation between height and occupational choice. Average marginal effects are calculated to improve the interpretation of the results. An OLS framework is adopted to investigate the determinants of hourly earnings. Work satisfaction and life satisfaction are analyzed via ordered logit regressions. Standard errors are clustered on the individual for each specification. We use gender, age, age squared, educational attainment, ${ }^{5}$ marital status, number of children, and German nationality as control variables in all the regressions. Regional dummy variables for the 16 German states are included in the regressions, together with year dummies for the nine years. Further, we add hourly income as a control variable when explaining work and life satisfaction (e.g., Benz and Frey, 2008; Binder and Coad, 2013).

Table 1 reports the descriptive statistics for the main variables of interest - height, occupational status, hourly earnings, work satisfaction, and life satisfaction — together with the control variables. Variable definitions are also provided. Table 2 shows differences in average height across occupational status, hourly earnings, work satisfaction, and life satisfaction, for both women and men. For earnings (below and above average) and the satisfaction variables (below and above 5), the average height for the lower half of the distribution is compared with that of the upper half of the distribution. The results show that self-employed individuals are taller than paid employees on average, independent of gender. Furthermore, for women and men, average height appears to increase as hourly wages increase and as one's work and life satisfaction scores increase.

\section{Results}

\subsection{Height and occupational choice}

Based on the arguments in the first section, we expect height to be positively associated with an individual's occupational choice for self-employment rather than paid employment. Table 3 (Model 1) reports the average marginal effects from a binary logit regression with self-employed as the dependent variable and height as the independent variable. The regression results show that taller individuals are more likely to be self-employed than paid employees when we control for our set of control variables. Every centimeter increase in height is associated with a 0.21 -percentage-point increase in the probability of being self-employed. Thus, the predicted probability of being selfemployed can be substantially different for persons with different heights and the same values for the

\footnotetext{
${ }^{5} \mathrm{We}$ also have an education variable that is better able to reflect the level of education rather than the number of years in education. Using this education variable with 9 categories in our analysis leads to qualitatively similar results.
} 
control variables. As the predicted probability of being self-employed is $11 \%$ (see Table 1), the relative increase $\mathrm{e}^{6}$ associated with a one-centimeter increase is $2.0 \%$.

Prior research demonstrates that the height premium for earnings can be partially explained by cognitive abilities (Case and Paxson, 2008; Case et al., 2009). We investigate whether educational attainment mediates the relationship between height and occupational choice. For this purpose, Model 2 in Table 3 adds the number of years of education to the model specification. The value of the marginal effect associated with the height variable decreases by about $23 \%$ but remains significant at the $0.1 \%$ level (it becomes 0.16 -percentage-point). We therefore conclude that educational attainment plays an important role in explaining the height differences between self-employed individuals and paid employees but that other factors for which we cannot control in our model specification certainly affect this relation as well.

Our dataset allows us to distinguish between self-employed individuals without employees (ownaccount workers) and self-employed individuals with employees (employers). We therefore assess whether the association between height and self-employment depends on whether the self-employed individual has employees (a proxy for social status within self-employment). The average marginal effects that result from a multinomial logit regression are displayed in Table 4. Specifically, Table 4 presents three sets of marginal effects: one set for wage employees, another set for own-account workers, and a final set for employers. Considering these results, we conclude that height is more strongly related to self-employment with employees than to self-employment without employees. That is, a one-centimeter increase in height is associated with a 0.05 -percentage-point increase in the probability of being an own-account worker $(p>0.10)$ and a 0.11 -percentage-point increase in the probability of being an employer $(p<0.001){ }^{7}$ In other words, the height difference between selfemployed individuals and paid employees is primarily attributable to the employers within the selfemployment group. This result is consistent with the notion that self-employed individuals with higher social status (because they employ others) are taller than self-employed individuals with lower status (who work on their own account).

\subsection{Height and hourly earnings}

We perform OLS regressions with hourly earnings as the dependent variable (in logarithms) and height as the independent variable to determine the magnitude of the height premium. Model 1 in Table 5 shows that the height premium is $0.88 \%$ in terms of hourly earnings for every centimeter of

\footnotetext{
${ }^{6}$ This is also known as the quasi-elasticity, defined as the ratio between the marginal effect and the baseline predicted probability of being self-employed rather than a paid employee.

${ }^{7}$ A test for similar marginal effects of height for own-account workers and employers yields a rejection $(p<0.05)$. Additional calculations (not tabulated) reveal that the relative increases are $0.8 \%$ and $2.2 \%$ for own-account workers and employers, respectively.
} 
an individual's height. An additional analysis (not tabulated) concludes that the elasticity between height and hourly earnings is $1.53 \%$, i.e., every percent increase in height is associated with a $1.53 \%$ increase in hourly earnings. Note, however, that self-employment itself is associated with lower hourly wages. There is prior evidence indicating that self-employed individuals earn less on average than paid employees (Hamilton, 2000).

Using Model 2 in Table 5, we investigate whether the height premium differs between paid employees and self-employed individuals. To do so, we include an interaction term between height and the self-employment variable. The coefficient of the interaction term is not significant, providing no evidence for a significantly different height premium between the two groups of workers.

Model 3 and Model 4 repeat the previous two exercises with educational attainment included. As Model 3 shows, for every centimeter of height, the height premium for the entire sample declines from $0.88 \%$ to $0.49 \%$ (a reduction of $44 \%$ ), whereas the elasticity (not tabulated) declines from $1.53 \%$ to $0.85 \%$. Model 4 adds the interaction term between height and self-employment, and the coefficient is significant at $5 \%$. Interestingly, the height premium for self-employed individuals is twice as large as that for paid employees. That is, a one-centimeter increase in height is associated with a $0.44 \%$ increase in hourly earnings for paid employees and a $0.87 \%$ increase for self-employed individuals. Thus, the inclusion of educational attainment in the model reduces the height premium for paid employees by nearly $50 \%$ but plays a less important role for self-employed individuals (a reduction of $23 \%) .{ }^{8}$ In summary, after controlling for educational attainment, we find a substantially higher height premium in hourly earnings for self-employed individuals than for paid employees.

We calculate the predicted earnings for short and tall individuals. The predicted earnings differences are substantial. That is, when we compare the predicted hourly earnings for short paid employeesfirst quartile of height: $166.4 \mathrm{~cm}$ — and for tall paid employees — third quartile of height: $180.0 \mathrm{~cm}$ the following results are found. The shortest paid employees earn 15.5 Euros per hour whereas the tallest paid employees earn 16.5 Euros per hour. For the shortest and tallest self-employed individuals the predicted hourly earnings are 12.8 and 14.4 Euros per hour, respectively. Indeed, self-employed individuals have lower predicted hourly earnings than paid employed individuals on average. ${ }^{9}$

Importantly, the above results are obtained with a linear height variable included in Table 5. This means that non-linear specifications for the relationship between height and earnings as described in Hübler (2009) are not considered. Examinations of non-linear effects of height on hourly earnings confirm that a linear effect prevails. That is, when a quadratic term of height is added to Model 3 in

\footnotetext{
${ }^{8}$ Other calculations (values not tabulated) reveal that the elasticity between height and hourly earnings is $0.77 \%$ for paid employees and $1.52 \%$ for self-employed individuals.

${ }^{9}$ The predicted earnings are 13.5 and 14.5 Euros per hour for short and tall women, respectively. The earnings are 16.9 and 18.1 Euros per hour for short and tall men, respectively.
} 
Table 5 both terms of height have non-significant coefficients $(p>0.10)$. In addition, the interaction terms between the self-employment variable and the linear and quadratic terms of height (comparable to Model 4 in Table 5) are non-significant $(p>0.10)$. The same conclusions are obtained when a quadratic and cubic term are added to Models 3 and 4. Another specification replaces the linear height variable in Model 3 with height-interval dummies, i.e., height is divided into $5 \mathrm{~cm}$ intervals (cf. Hübler, 2009). Interestingly, the coefficients of the interval dummies increase monotonically in height. The coefficients belonging to the alternative height variables in Model 3 (Table 5) are provided in the footnote of Table $5 .{ }^{10}$

\subsection{Height and satisfaction}

To investigate whether a height premium also exists for outcomes other than earnings, we adopt work satisfaction and life satisfaction as our dependent variables. Ordered probit regressions are performed with these two dependent variables and height as the independent variable. Note that we control for hourly income in these regressions because income is a relevant determinant of work and life satisfaction (see, e.g., Benz and Frey, 2008; Binder and Coad, 2013). Table 6 contains the estimates for work satisfaction, and Table 7 for life satisfaction. Model 1 in each table shows that height is positively associated with both work satisfaction (Table 6) and life satisfaction (Table 7). Further, we find significant, positive associations between self-employment and work and life satisfaction, which corroborates the findings of earlier studies (e.g., Hundley (2001) and Andersson (2008)).

Model 2 in each table includes an interaction term between height and self-employment to assess whether the height premium differs between the two groups of workers. The coefficients of the interaction terms are significant and negative (at 5\%), implying a significantly smaller height premium for self-employment than for paid employment. Specifically, the height premium for work and life satisfaction is present only for paid employees and is absent for self-employed workers. ${ }^{11}$

Models 3 and 4 (Tables 6 and 7) repeat the above exercises but with educational attainment included. The mediating role of education in the relationship between height and satisfaction is generally not present. That is, the estimated coefficients of height in Model 3 change little compared to those in Model 1. In addition, the coefficients of the interaction terms in Model 4 are similar to those in Model 2.

\footnotetext{
${ }^{10}$ The coefficients of the interaction terms for each alternative model specification are available from the authors on request.

${ }^{11}$ Additional tests on the linear combination of the coefficient of the height variable and the coefficient of the interaction term show that height does not have a significant relationship ( $p$-values $>0.10$ ) with work or life satisfaction for the group of self-employed individuals.
} 


\section{Discussion and conclusion}

Using data from the German Socio-Economic Panel, we find that taller individuals are more likely to be self-employed than wage workers. Moreover, this positive relationship between self-reported height and self-employment versus paid employment is much stronger for employers than for ownaccount workers. In this way, the findings for the present study are consistent with prior research indicating that height and job status are positively associated (Case and Paxson, 2006; Lindqvist, 2012). That is, employers can be expected to receive higher levels of status and respect than ownaccount workers. Indeed, we noted above that employers are characterized by higher levels of entrepreneurial ability than own-account workers (Congregado et al., 2010). In addition, further calculations based on the current German sample reveal that employers have significantly higher income and education levels than own-account workers. ${ }^{12}$ Income and education are two well-known aspects related to occupational status (Fershtman and Weiss, 1993).

Our results also reveal a height premium in hourly earnings within the group of self-employed individuals. Whereas prior research finds such a height premium in various settings among paid employees (Case and Paxson, 2006), a novel aspect of the present study is that we compare the height premium between individuals in self-employment and individuals in paid employment. We conclude that the premium is significantly higher for self-employed individuals than for paid employees, at least in our German sample. It is known from existing studies that height is positively associated with (non)cognitive abilities (Schick and Steckel, 2010), and in our sample, we observe higher education levels for taller persons (results not tabulated). The higher height premium for self-employed individuals can then be explained by the greater returns to ability, such as those from education and intelligence, in self-employment relative to paid employment (see Parker and Van Praag (2010) for a review of the literature on this subject).

In addition to hourly earnings, we assess the existence of a height premium in work and life satisfaction, again for both paid employees and self-employed individuals. Interestingly, we find a height premium in work and life satisfaction for paid employees only, not for self-employed individuals. Our findings that the height premium for self-employed workers exceeds that of paid employed workers in the case of earnings but is absent in the case of satisfaction provides an interesting research direction for future research. Clearly, tallness is beneficial for self-employed

\footnotetext{
${ }^{12}$ Interestingly, the OLS results from Table 5 (Models 1 and 3) indicate that self-employed individuals earn less than wage workers (cf. Hamilton, 2000). These additional calculations reveal that the group of own-account workers earn less than wage workers and that employers earn significantly more than the own-account workers (and wage workers). The higher status accorded to the self-employed-based on evidence from the Global Entrepreneurship Monitor and Eurobarometer surveys (see the introductory section) — can therefore be ascribed to employers within the self-employed group.
} 
individuals, but only in terms of earnings. Which aspects of life are perceived to be less rewarding or are appreciated less by taller self-employed individuals to the extent that they ultimately have similar work and life satisfaction levels to shorter self-employed individuals remain unclear from the findings of the present study. ${ }^{13}$ In general, we believe that it is important to focus on other, and more encompassing, measures of utility than financial returns alone, and we call for additional research on the intersection of (several domains of) life satisfaction and occupational choice.

The present paper reveals that educational attainment partly explains why taller persons are more likely to be self-employed than paid employees. In addition, educational attainment plays a role in explaining the height premium in earnings among both self-employed individuals and paid employees. However, the mediating role of education is generally not observed for our two types of satisfaction, suggesting that non-cognitive skills play a more substantial role in explaining the height premium in satisfaction. Our analysis suggests that education plays a much more important role in individuals' level of earnings than individuals' level of work and life satisfaction. By contrast, noncognitive skills such as work practices (e.g., effort, determination) and individual traits (e.g., selfconfidence, sociability) (Ter Weel, 2008) may be highly relevant to how one evaluates satisfaction with one's work and life and hence may play a substantial role in explaining the relationship between height and satisfaction. We encourage future research to validate our results by using more appropriate proxies for cognitive skills and by assessing the role of non-cognitive skills in a research design involving multiple countries where entrepreneurs are accorded different levels of social status.

To conclude, the present study extends previous research on the role of an individual's stature in labor market outcomes in four ways while devoting particular attention to the occupational choice between self-employment and paid employment. First, we find that the occupational choice between selfemployment and paid employment depends on height, and we relate this finding to the higher stature of self-employed individuals, particularly employers within the self-employed group. Second, we find that a height premium in hourly earnings exists for the self-employed and that this height premium is larger for self-employed individuals $(0.87 \%)$ than for paid employees $(0.44 \%)$. Third, we find a height premium in work and life satisfaction for paid employees but not for self-employed individuals. Finally, we find that educational attainment has a mediating role in explaining the relationship between height and both occupational choice (for 23\%) and earnings (44\%) but little role in explaining the relationship between height and work and life satisfaction.

${ }^{13}$ Certain (sub)dimensions of life satisfaction may be less rewarding for certain groups of self-employed persons. Because tall, self-employed persons tend to be employers rather than own-account workers (Table 4), employers may have low levels of leisure time satisfaction (confirmed by the data) because their work is more time consuming, which may explain why tallness within self-employment is not related to life (or work) satisfaction. 
Table 1. Summary statistics main variables of interest and control variables.

\begin{tabular}{|c|c|c|c|c|c|c|}
\hline Variable & Obs. & Mean & SD & Min. & Max. & Definition \\
\hline Height & 93,023 & 173.08 & 9.20 & 131.20 & 208.67 & $\begin{array}{l}\text { Average self-reported height in } \\
\text { centimetres. }\end{array}$ \\
\hline Self-employed & 93,023 & 0.11 & 0.31 & 0 & 1 & $\begin{array}{l}1=\text { self-employed; } 0=\text { paid } \\
\text { employed. }\end{array}$ \\
\hline Hourly earnings (log) & 91,033 & 2.60 & 0.66 & -4.31 & 7.32 & $\begin{array}{l}\text { Annual earnings divided by } \\
\text { annual work hours. }\end{array}$ \\
\hline Work satisfaction & 91,040 & 7.01 & 1.99 & 0 & 10 & $\begin{array}{l}0=\text { completely dissatisfied; } \\
10=\text { completely satisfied. }\end{array}$ \\
\hline Life satisfaction & 92,860 & 7.10 & 1.64 & 0 & 10 & $\begin{array}{l}0=\text { completely dissatisfied; } \\
10=\text { completely satisfied. }\end{array}$ \\
\hline Male & 93,023 & 0.52 & 0.50 & 0 & 1 & $1=$ male; $0=$ female \\
\hline Age & 93,023 & 42.94 & 10.73 & 18 & 65 & Respondent's age in years. \\
\hline Education in years & 90,610 & 12.83 & 2.76 & 7 & 18 & Number of years of education. \\
\hline \multicolumn{7}{|l|}{ Marital status } \\
\hline Married & 93,020 & 0.64 & 0.48 & 0 & 1 & $1=$ currently married; $0=$ other. \\
\hline $\begin{array}{l}\text { Divorced/separated/ } \\
\text { widowed }\end{array}$ & 93,020 & 0.12 & 0.33 & 0 & 1 & $\begin{array}{l}1=\text { divorced/separated/ } \\
\text { widowed; } 0=\text { otherwise. }\end{array}$ \\
\hline Never married & 93,020 & 0.24 & 0.43 & 0 & 1 & $\begin{array}{l}\text { Reference category in } \\
\text { regressions. }\end{array}$ \\
\hline Children & 93,023 & 0.64 & 0.92 & 0 & 5 & $\begin{array}{l}\text { Number of children in } \\
\text { household: } 0,1,2,3,4, \geq 5 \text {. }\end{array}$ \\
\hline German & 93,023 & 0.94 & 0.24 & 0 & 1 & $\begin{array}{l}1=\text { German nationality; } 0=\text { other } \\
\text { nationality. }\end{array}$ \\
\hline
\end{tabular}

Notes: Source: GSOEP (2002-2010). Abbreviations: Obs.=number of non-missing observations; SD=standard deviation; Min.=minimum value; Max.=maximum value. The properties of the region dummies are not provided here, but are available from the authors upon request. The 16 regions being distinguished are Baden-Wuerttemberg, Bavaria, Berlin, Brandenburg, Bremen, Hamburg, Hessen, Lower Saxony, Mecklenburg-Vorpomme, North-Rhine-Westfalia, Rheinland-Pfalz, Saarland, Saxony, Saxony-Anhalt, Schleswig-Holstein, and Thuringia.

Table 2. Average height (in $\mathrm{cm}$ ) across occupational status, earnings, and satisfaction, for men and women.

\begin{tabular}{lccc}
\hline Subgroup & All & Women & Men \\
\hline Paid employment & 172.82 & 166.29 & 179.14 \\
Self-employment & 175.30 & 166.98 & 179.74 \\
& & & 178.65 \\
Hourly earnings (log): <=average & 171.38 & 166.09 & 179.59 \\
Hourly earnings (log): >average & 174.71 & 166.73 & 178.62 \\
& & & 179.38 \\
Work satisfaction: 0-5 & 172.47 & 165.91 & 178.26 \\
Work satisfaction: 6-10 & 173.29 & 166.47 & 179.40 \\
& & & 165.64 \\
Life satisfaction: 0-5 & 171.92 & 166.50 & . \\
Life satisfaction: 6-10 & 173.32 & & \\
\hline
\end{tabular}

Notes: Source: GSOEP (2002-2010). Regular $t$-tests show that all height differences for each pair of subgroups are significant at the $0.1 \%$ level. 
Table 3. Estimated marginal effects based on binary logit regressions. Dependent variable: self-employment versus paid employment.

\begin{tabular}{|c|c|c|}
\hline & $\begin{array}{c}\text { (1) } \\
\text { Excluding education }\end{array}$ & $\begin{array}{c}\text { (2) } \\
\text { Including education }\end{array}$ \\
\hline Height & $\begin{array}{l}0.0021 * * * \\
(0.0004)\end{array}$ & $\begin{array}{l}0.0016 * * * \\
(0.0004)\end{array}$ \\
\hline Male & $\begin{array}{l}0.026 \text { *** } \\
(0.007)\end{array}$ & $\begin{array}{l}0.030 \text { *** } \\
(0.007)\end{array}$ \\
\hline Age & $\begin{array}{l}0.004 * * * \\
(0.0003)\end{array}$ & $\begin{array}{l}0.003 * * * \\
(0.0003)\end{array}$ \\
\hline Education in years & & $\begin{array}{l}0.009 * * * \\
(0.0008)\end{array}$ \\
\hline Married & $\begin{array}{l}-0.029 * * \\
(0.009)\end{array}$ & $\begin{array}{l}-0.021 * \\
(0.008)\end{array}$ \\
\hline Divorced/separated/widowed & $\begin{array}{l}-0.011 \\
(0.010)\end{array}$ & $\begin{array}{c}0.002 \\
(0.010)\end{array}$ \\
\hline Children & $\begin{array}{l}0.015^{* * * *} \\
(0.003)\end{array}$ & $\begin{array}{l}0.013 \text { *** } \\
(0.003)\end{array}$ \\
\hline German & $\begin{array}{c}0.019 \\
(0.011)\end{array}$ & $\begin{array}{c}0.002 \\
(0.011)\end{array}$ \\
\hline Region dummies & YES & YES \\
\hline Year dummies & YES & YES \\
\hline Number of observations & 93,020 & 90,607 \\
\hline Number of individuals & 19,379 & 18,624 \\
\hline$R^{2}$ & 0.04 & 0.05 \\
\hline
\end{tabular}

Table 4. Estimated marginal effects based on mulitnomial logit regression. Dependent variable: paid employment (1; PE); self-employment (SE) without employees (2); self-employment with employees (3).

\begin{tabular}{|c|c|c|c|}
\hline & $\begin{array}{l}\text { (1) } \\
\mathrm{PE}\end{array}$ & $\begin{array}{c}\text { (2) } \\
\text { SE without employees }\end{array}$ & $\begin{array}{c}\text { (3) } \\
\text { SE with employees }\end{array}$ \\
\hline Height & $\begin{array}{l}-0.0016 * * * \\
(0.0004)\end{array}$ & $\begin{array}{c}0.0005 \\
(0.0002)\end{array}$ & $\begin{array}{l}0.0011 * * * \\
(0.0003)\end{array}$ \\
\hline Male & $\begin{array}{l}-0.032 * * * \\
(0.007)\end{array}$ & $\begin{array}{l}-0.0001 \\
(0.005)\end{array}$ & $\begin{array}{l}0.032 * * * \\
(0.005)\end{array}$ \\
\hline Age & $\begin{array}{l}-0.003 * * * \\
(0.0003)\end{array}$ & $\begin{array}{l}0.002 * * * \\
(0.0002)\end{array}$ & $\begin{array}{l}0.002 * * * \\
(0.0002)\end{array}$ \\
\hline Education in years & $\begin{array}{l}-0.009 * * * \\
(0.0008)\end{array}$ & $\begin{array}{l}0.003 * * * \\
(0.0006)\end{array}$ & $\begin{array}{l}0.006 * * * \\
(0.0006)\end{array}$ \\
\hline Married & $\begin{array}{l}0.020^{*} \\
(0.008)\end{array}$ & $\begin{array}{l}-0.024 * * * \\
(0.006)\end{array}$ & $\begin{array}{c}0.004 \\
(0.005)\end{array}$ \\
\hline $\begin{array}{l}\text { Divorced/separated/ } \\
\text { widowed }\end{array}$ & $\begin{array}{l}-0.002 \\
(0.010)\end{array}$ & $\begin{array}{l}-0.011 \\
(0.008)\end{array}$ & $\begin{array}{c}0.014 \\
(0.007)\end{array}$ \\
\hline Children & $\begin{array}{l}-0.012 * * * \\
(0.003)\end{array}$ & $\begin{array}{l}0.005 * * \\
(0.002)\end{array}$ & $\begin{array}{l}0.007 * * * \\
(0.002)\end{array}$ \\
\hline German & $\begin{array}{l}-0.002 \\
(0.011)\end{array}$ & $\begin{array}{c}0.006 \\
(0.008)\end{array}$ & $\begin{array}{l}-0.004 \\
(0.007)\end{array}$ \\
\hline Region dummies & YES & YES & YES \\
\hline Year dummies & YES & YES & YES \\
\hline Number of observations & & 90,607 & \\
\hline Number of individuals & & 18,624 & \\
\hline$R^{2}$ & & 0.05 & \\
\hline
\end{tabular}


Table 5. Estimated coefficients from OLS regressions with $\log ($ hourly earnings) as the dependent variable.

\begin{tabular}{|c|c|c|c|c|}
\hline & $\begin{array}{c}\text { (1) } \\
\text { Excluding } \\
\text { education, } \\
\text { excluding } \\
\text { interaction }\end{array}$ & $\begin{array}{c}(2) \\
\text { Excluding } \\
\text { education, } \\
\text { including } \\
\text { interaction }\end{array}$ & $\begin{array}{c}\text { (3) } \\
\text { Including } \\
\text { education, } \\
\text { excluding } \\
\text { interaction }\end{array}$ & $\begin{array}{l}\text { (4) } \\
\text { Including } \\
\text { education, } \\
\text { including } \\
\text { interaction }\end{array}$ \\
\hline Height & $\begin{array}{c}0.0088^{* * *} \\
(0.0006)\end{array}$ & $\begin{array}{c}0.0085^{* * *} \\
(0.0006)\end{array}$ & $\begin{array}{c}0.0049 * * * \\
(0.0006)\end{array}$ & $\begin{array}{l}0.0044 * * * \\
(0.0006)\end{array}$ \\
\hline Self-employed & $\begin{array}{l}-0.091 * * * \\
(0.018)\end{array}$ & $\begin{array}{l}-0.583 \\
(0.356)\end{array}$ & $\begin{array}{l}-0.159 * * * \\
(0.017)\end{array}$ & $\begin{array}{l}-0.904 * * \\
(0.340)\end{array}$ \\
\hline Height $\times$ Self-employed & & $\begin{array}{c}0.003 \\
(0.002)\end{array}$ & & $\begin{array}{c}0.004^{*} \\
(0.002)\end{array}$ \\
\hline Male & $\begin{array}{l}0.173 * * * \\
(0.012)\end{array}$ & $\begin{array}{l}0.173 * * * \\
(0.012)\end{array}$ & $\begin{array}{l}0.223^{* * *} \\
(0.011)\end{array}$ & $\begin{array}{l}0.223 * * * \\
(0.011)\end{array}$ \\
\hline Age & $\begin{array}{l}0.060 * * * \\
(0.003)\end{array}$ & $\begin{array}{l}0.060 * * * \\
(0.003)\end{array}$ & $\begin{array}{l}0.048 * * * \\
(0.003)\end{array}$ & $\begin{array}{l}0.048 * * * \\
(0.003)\end{array}$ \\
\hline Age squared & $\begin{array}{l}-0.0005 * * * \\
(0.00003)\end{array}$ & $\begin{array}{l}-0.0005 * * * \\
(0.00003)\end{array}$ & $\begin{array}{l}-0.0004 * * * \\
(0.00003)\end{array}$ & $\begin{array}{l}-0.0004 * * * \\
(0.00003)\end{array}$ \\
\hline Education in years & & & $\begin{array}{l}0.080 * * * \\
(0.001)\end{array}$ & $\begin{array}{l}0.080 * * * \\
(0.001)\end{array}$ \\
\hline Married & $\begin{array}{c}0.023 \\
(0.013)\end{array}$ & $\begin{array}{c}0.023 \\
(0.013)\end{array}$ & $\begin{array}{l}0.074 * * * \\
(0.012)\end{array}$ & $\begin{array}{l}0.074 * * * \\
(0.012)\end{array}$ \\
\hline Divorced/separated/widowed & $\begin{array}{l}-0.052^{* *} \\
(0.016)\end{array}$ & $\begin{array}{l}-0.051^{* *} \\
(0.016)\end{array}$ & $\begin{array}{c}0.036^{*} \\
(0.015)\end{array}$ & $\begin{array}{c}0.037 * \\
(0.015)\end{array}$ \\
\hline Children & $\begin{array}{l}0.016^{* *} \\
(0.005)\end{array}$ & $\begin{array}{l}0.016^{* * *} \\
(0.005)\end{array}$ & $\begin{array}{c}0.008 \\
(0.004)\end{array}$ & $\begin{array}{c}0.008 \\
(0.004)\end{array}$ \\
\hline German & $\begin{array}{l}0.139 * * * \\
(0.016)\end{array}$ & $\begin{array}{l}0.139 * * * \\
(0.016)\end{array}$ & $\begin{array}{c}0.021 \\
(0.015)\end{array}$ & $\begin{array}{c}0.021 \\
(0.015)\end{array}$ \\
\hline Region dummies & YES & YES & YES & YES \\
\hline Year dummies & YES & YES & YES & YES \\
\hline Number of observations & 91,030 & 91,030 & 88,780 & 88,780 \\
\hline Number of individuals & 18,986 & 18,986 & 18,285 & 18,285 \\
\hline$R^{2}$ & 0.18 & 0.18 & 0.28 & 0.28 \\
\hline
\end{tabular}

Notes: $* * * p<0.001, * * p<0.01, * p<0.05$. Robust standard errors (between parentheses) are clustered on the individual. The reference category for marital status is "never married".

Coefficients alternative height specifications in Model 3:

a) linear and quadratic term: $0.010(0.012)$ and -0.00001 (0.00003);

b) linear, quadratic, and cubic term: -0.205 (0.182), 0.001 (0.001), and -0.000002 (0.000002);

c) height-interval dummies: $150<$ height $\leq 155$ : $-0.093 *(0.040) ; \quad 155<$ height $\leq 160$ : $-0.084 * * *(0.021)$;

$160<$ height $\leq 165:-0.041^{* *}(0.015) ; 165<$ height $\leq 170:-0.024(0.013)$;

$170<$ height $\leq 175$ : reference dummy; $175<$ height $\leq 180$ : $0.021(0.012)$;

$180<$ height $\leq 185: 0.067 * * *(0.014) ; 185<$ height $\leq 190: 0.067 * * *(0.018)$ :

$190<$ height $\leq 195: 0.093^{* * *}(0.022) ; 195<$ height $\leq 200: 0.096^{*}(0.045)$. 
Table 6. Estimated coefficients from ordered logit regressions with work satisfaction (values 0-10) as the dependent variable.

\begin{tabular}{|c|c|c|c|c|}
\hline & $\begin{array}{l}\text { (1) } \\
\text { Excluding } \\
\text { education, } \\
\text { excluding } \\
\text { interaction }\end{array}$ & $\begin{array}{l}\text { (2) } \\
\text { Excluding } \\
\text { education, } \\
\text { including } \\
\text { interaction }\end{array}$ & $\begin{array}{c}\text { (3) } \\
\text { Including } \\
\text { education, } \\
\text { excluding } \\
\text { interaction }\end{array}$ & $\begin{array}{c}\text { (4) } \\
\text { Including } \\
\text { education, } \\
\text { including } \\
\text { interaction }\end{array}$ \\
\hline Height & $\begin{array}{l}0.0065^{* * * *} \\
(0.0018)\end{array}$ & $\begin{array}{l}0.0075 * * * \\
(0.0018)\end{array}$ & $\begin{array}{l}0.0062 * * * \\
(0.0018)\end{array}$ & $\begin{array}{l}0.0071 \text { *** } \\
(0.0018)\end{array}$ \\
\hline Self-employed & $\begin{array}{l}0.326 * * * \\
(0.036)\end{array}$ & $\begin{array}{l}2.082 * * \\
(0.734)\end{array}$ & $\begin{array}{l}0.304 * * * \\
(0.037)\end{array}$ & $\begin{array}{l}2.042 * * \\
(0.744)\end{array}$ \\
\hline Height $\times$ Self-employed & & $\begin{array}{l}-0.010 * \\
(0.004)\end{array}$ & & $\begin{array}{l}-0.010 * \\
(0.004)\end{array}$ \\
\hline Hourly earnings (log) & $\begin{array}{l}0.327 * * * \\
(0.018)\end{array}$ & $\begin{array}{l}0.328 * * * \\
(0.018)\end{array}$ & $\begin{array}{l}0.291 * * * \\
(0.019)\end{array}$ & $\begin{array}{l}0.292 * * * \\
(0.019)\end{array}$ \\
\hline Male & $\begin{array}{l}-0.218 * * * \\
(0.032)\end{array}$ & $\begin{array}{l}-0.219 * * * \\
(0.032)\end{array}$ & $\begin{array}{l}-0.196 * * * \\
(0.032)\end{array}$ & $\begin{array}{l}-0.197 * * * \\
(0.032)\end{array}$ \\
\hline Age & $\begin{array}{l}-0.098 * * * \\
(0.008)\end{array}$ & $\begin{array}{l}-0.097 * * * \\
(0.008)\end{array}$ & $\begin{array}{l}-0.102 * * * \\
(0.008)\end{array}$ & $\begin{array}{l}-0.102 * * * \\
(0.008)\end{array}$ \\
\hline Age squared & $\begin{array}{l}0.001 * * * \\
(0.0001)\end{array}$ & $\begin{array}{l}0.001 * * * \\
(0.0001)\end{array}$ & $\begin{array}{l}0.001 * * * \\
(0.0001)\end{array}$ & $\begin{array}{l}0.001 * * * \\
(0.0001)\end{array}$ \\
\hline Education in years & & & $\begin{array}{l}0.019 * * * \\
(0.004)\end{array}$ & $\begin{array}{l}0.019 * * * \\
(0.004)\end{array}$ \\
\hline Married & $\begin{array}{l}0.119 * * * \\
(0.034)\end{array}$ & $\begin{array}{l}0.118 * * * \\
(0.034)\end{array}$ & $\begin{array}{l}0.135^{* * * *} \\
(0.034)\end{array}$ & $\begin{array}{l}0.134 * * * \\
(0.034)\end{array}$ \\
\hline $\begin{array}{l}\text { Divorced/separated/ } \\
\text { widowed }\end{array}$ & $\begin{array}{r}0.102 * \\
(0.044)\end{array}$ & $\begin{array}{l}0.100 * \\
(0.044)\end{array}$ & $\begin{array}{l}0.126 * * \\
(0.045)\end{array}$ & $\begin{array}{l}0.124 * * \\
(0.045)\end{array}$ \\
\hline Children & $\begin{array}{l}0.079 * * * \\
(0.013)\end{array}$ & $\begin{array}{l}0.079 * * * \\
(0.013)\end{array}$ & $\begin{array}{l}0.077 * * * \\
(0.013)\end{array}$ & $\begin{array}{l}0.077 * * * \\
(0.013)\end{array}$ \\
\hline German & $\begin{array}{l}0.180 * * * \\
(0.045)\end{array}$ & $\begin{array}{l}0.180 * * * \\
(0.045)\end{array}$ & $\begin{array}{l}0.155^{* * *} * \\
(0.046)\end{array}$ & $\begin{array}{l}0.155^{* * * *} \\
(0.046)\end{array}$ \\
\hline Region dummies & YES & YES & YES & YES \\
\hline Year dummies & YES & YES & YES & YES \\
\hline Number of observations & 89,324 & 89,324 & 87,241 & 87,241 \\
\hline Number of individuals & 18,667 & 18,667 & 18,034 & 18,034 \\
\hline$R^{2}$ & 0.01 & 0.01 & 0.01 & 0.01 \\
\hline
\end{tabular}

Notes: $* * * p<0.001, * * p<0.01, * p<0.05$. Robust standard errors (between parentheses) are clustered on the individual. The reference category for marital status is "never married". Estimates of the threshold parameters are not shown. 
Table 7. Estimated coefficients from ordered logit regressions with life satisfaction (values 0-10) as the dependent variable.

\begin{tabular}{|c|c|c|c|c|}
\hline & $\begin{array}{l}\text { (1) } \\
\text { Excluding } \\
\text { education, } \\
\text { excluding } \\
\text { interaction }\end{array}$ & $\begin{array}{c}\text { (2) } \\
\text { Excluding } \\
\text { education, } \\
\text { including } \\
\text { interaction }\end{array}$ & $\begin{array}{c}\text { (3) } \\
\text { Including } \\
\text { education, } \\
\text { excluding } \\
\text { interaction }\end{array}$ & $\begin{array}{c}\text { (4) } \\
\text { Including } \\
\text { education, } \\
\text { including } \\
\text { interaction }\end{array}$ \\
\hline Height & $\begin{array}{l}0.0116^{* * * *} \\
(0.0018)\end{array}$ & $\begin{array}{l}0.0126^{* * * *} \\
(0.0019)\end{array}$ & $\begin{array}{l}0.0095^{* * * *} \\
(0.0019)\end{array}$ & $\begin{array}{l}0.0104 * * * \\
(0.0019)\end{array}$ \\
\hline Self-employed & $\begin{array}{l}0.156 * * * \\
(0.036)\end{array}$ & $\begin{array}{l}1.965^{* *} \\
(0.731)\end{array}$ & $\begin{array}{c}0.090 * \\
(0.037)\end{array}$ & $\begin{array}{c}1.695^{*} \\
(0.754)\end{array}$ \\
\hline Height $\times$ Self-employed & & $\begin{array}{l}-0.010 * \\
(0.004)\end{array}$ & & $\begin{array}{l}-0.009 * \\
(0.004)\end{array}$ \\
\hline Hourly earnings (log) & $\begin{array}{l}0.498 * * * \\
(0.018)\end{array}$ & $\begin{array}{l}0.499 * * * \\
(0.018)\end{array}$ & $\begin{array}{l}0.400 * * * \\
(0.019)\end{array}$ & $\begin{array}{l}0.401 * * * \\
(0.019)\end{array}$ \\
\hline Male & $\begin{array}{l}-0.338^{* * * *} \\
(0.034)\end{array}$ & $\begin{array}{l}-0.339 * * * \\
(0.034)\end{array}$ & $\begin{array}{l}-0.279 * * * \\
(0.035)\end{array}$ & $\begin{array}{l}-0.281 * * * \\
(0.035)\end{array}$ \\
\hline Age & $\begin{array}{l}-0.131 * * * \\
(0.008)\end{array}$ & $\begin{array}{l}-0.131 * * * \\
(0.008)\end{array}$ & $\begin{array}{l}-0.133 * * * \\
(0.008)\end{array}$ & $\begin{array}{l}-0.132 * * * \\
(0.008)\end{array}$ \\
\hline Age squared & $\begin{array}{l}0.001 * * * \\
(0.0001)\end{array}$ & $\begin{array}{l}0.001 * * * \\
(0.0001)\end{array}$ & $\begin{array}{l}0.001 * * * \\
(0.0001)\end{array}$ & $\begin{array}{l}0.001 * * * \\
(0.0001)\end{array}$ \\
\hline Education in years & & & $\begin{array}{l}0.061 * * * \\
(0.005)\end{array}$ & $\begin{array}{l}0.061^{* * * *} \\
(0.005)\end{array}$ \\
\hline Married & $\begin{array}{l}0.270^{* * * *} \\
(0.036)\end{array}$ & $\begin{array}{l}0.269 * * * \\
(0.036)\end{array}$ & $\begin{array}{l}0.317 * * * \\
(0.037)\end{array}$ & $\begin{array}{l}0.316^{* * * *} \\
(0.037)\end{array}$ \\
\hline $\begin{array}{l}\text { Divorced/separated/ } \\
\text { widowed }\end{array}$ & $\begin{array}{l}-0.160 * * * \\
(0.046)\end{array}$ & $\begin{array}{l}-0.162 * * * \\
(0.046)\end{array}$ & $\begin{array}{l}-0.099 * \\
(0.047)\end{array}$ & $\begin{array}{l}-0.101^{*} \\
(0.047)\end{array}$ \\
\hline Children & $\begin{array}{l}0.047 * * * \\
(0.014)\end{array}$ & $\begin{array}{l}0.047 * * * \\
(0.014)\end{array}$ & $\begin{array}{l}0.039 * * \\
(0.014)\end{array}$ & $\begin{array}{l}0.039 * * \\
(0.014)\end{array}$ \\
\hline German & $\begin{array}{c}0.106^{*} \\
(0.046)\end{array}$ & $\begin{array}{c}0.105^{*} \\
(0.046)\end{array}$ & $\begin{array}{c}0.028 \\
(0.048)\end{array}$ & $\begin{array}{c}0.028 \\
(0.048)\end{array}$ \\
\hline Region dummies & YES & YES & YES & YES \\
\hline Year dummies & YES & YES & YES & YES \\
\hline Number of observations & 90,873 & 90,873 & 88,629 & 88,629 \\
\hline Number of individuals & 18,979 & 18,979 & 18,279 & 18,279 \\
\hline$R^{2}$ & 0.02 & 0.02 & 0.02 & 0.02 \\
\hline
\end{tabular}

Notes: $* * * p<0.001, * * p<0.01, * p<0.05$. Robust standard errors (between parentheses) are clustered on the individual. The reference category for marital status is "never married". Estimates of the threshold parameters are not shown. 


\section{References}

Alesina, A., Di Tella, R., MacCulloch, R. 2004. Inequality and happiness: Are Europeans and Americans different? Journal of Public Economics, 88(9), 2009-2042.

Andersson, P. 2008. Happiness and health: Well-being among the self-employed. Journal of SocioEconomics, 37(1), 213-236.

Benz, M., Frey, B.S. 2004. Being independent raises happiness at work. Swedish Economic Policy Review, 11(2), 95-134.

Benz, M., Frey, B.S. 2008. Being independent is a great thing: Subjective evaluations of selfemployment and hierarchy. Economica, 75(298), 362-383.

Bianchi, M. 2012. Financial development, entrepreneurship, and job satisfaction. Review of Economics and Statistics, 94(1), 273-286.

Binder, M., Coad, A. 2013. Life satisfaction and self-employment: A matching approach. Small Business Economics, 40, 1009-1033.

Blanchflower, D.G. 2000. Self-employment in OECD countries, Labour Economics, 7, 471-505.

Blanchflower, D.G., Oswald, A.J. 1998. What makes an entrepreneur? Journal of Labor Economics, 16(1), 26-60.

Case, A., Paxson, C. 2006. Stature and status: Height, ability and labor market outcomes. Journal of Political Economy, 116(3), 499-532.

Case, A., Paxson, C., Islam, M. (2009). Making sense of the labor market height premium: Evidence from the British Household Panel Survey. Economics Letters, 102(3), 174-176.

Clark, A., Oswald, A. 1996. Satisfaction and comparison income. Journal of Public Economics, 61, 359-381.

Congregado, E., Millán, J.M., Román, C. 2010, From own-account worker to job creator. International Review of Entrepreneurship, 8(4), 277-302.

Deaton, A., Arora, R. 2009. Life at the top: The benefits of height. Economics and Human Biology, 7, 133-136.

De Wit, G. 1993. Models of self-employment in a competitive market. Journal of Economic Surveys, 7, 367-397.

Djankov, S., Qian, Y., Roland, G., Zhuravskaya, E. 2006. Entrepreneurship in Brazil, China and Russia. CEFIR Working Paper 66. Moscow: Center for Economic and Financial Research.

Earle, J.S., Sakova, Z. 2000. Business start-ups or disguised unemployment? Evidence on the character of self-employment from transition economies. Labour Economics, 7, 575-601.

Fershtman, C., Weiss, Y. 1993. Social status, culture and economic performance. The Economic Journal, 103(419), 946-959.

Frey, B.S., Stutzer, A. 2002. What can economists learn from happiness research? Journal of Economic Literature, 402-435.

Gowin, E. 1915. The executive and his control of men. Macmillan: New York.

Hamilton, B.H. (2000). Does entrepreneurship pay? An empirical analysis of the returns to selfemployment. Journal of Political Economy, 108(3), 604-631.

Hübler, O. 2009. The nonlinear link between height and wages in Germany, 1985-2004. Economics \& Human Biology, 7(2), 191-199.

Hundley, G. 2001. Why and when are the self-employed more satisfied with their work? Industrial Relations, 40(2), 293-316.

Kelley, D.J., Bosma, N., Amorós, J.E. 2011. Global Entrepreneurship Monitor: Global report 2010. St. Louis, United States: Global Entrepreneurship Research Association.

Lindqvist, E. 2012. Height and leadership. Review of Economics and Statistics, 94(4), 1191-1196.

Millán, J.M., Hessels, J., Thurik, R., Aguado, R. 2013. Determinants of job satisfaction: A European comparison of self-employed and paid employees. Small Business Economics, 40(3), 651-670.

Parker, S.C. 2009. The economics of entrepreneurship. Cambridge University Press: Cambridge.

Parker, S.C., Van Praag, M. 2010. Group status and entrepreneurship. Journal of Economics \& Management Strategy, 19(4), 919-945. 
Persico, N., Postlewaite, A., Silverman, D. 2004. The effect of adolescent experience on labor market outcomes: The case of height. Journal of Political Economy, 112, 1019-1053.

Schick, A., Steckel, R.H. 2010. Height as a proxy for cognitive and non-cognitive ability. NBER Working paper series, Working Paper 16570.

Sohn, K. 2014. The height premium in Indonesia. Economics and Human Biology, forthcoming, DOI: http://dx.doi.org/10.1016/j.ehb.2013.12.011.

Tamvada, J.P. 2010. Entrepreneurship and welfare. Small Business Economics, 34(1), 65-79

Tao, H. 2014. Height, weight and entry earnings of female graduates in Taiwan. Economics and Human Biology, 13, 85-98.

Ter Weel, B. 2008. The noncognitive determinants of labor market and behavioral outcomes: Introduction to the symposium. Journal of Human Resources, 43(4), 729-737.

Van Praag, B.M.S., Ferrer-i-Carbonell, A. 2010. Happiness Economics: A new road to measuring and comparing happiness. Foundations and Trends in Microeconomics, 6(10), 1-97.

Van Stel, A. 2005. COMPENDIA: Harmonizing business ownership data across countries and over time. International Entrepreneurship Management Journal, 1(1), 105-123. 